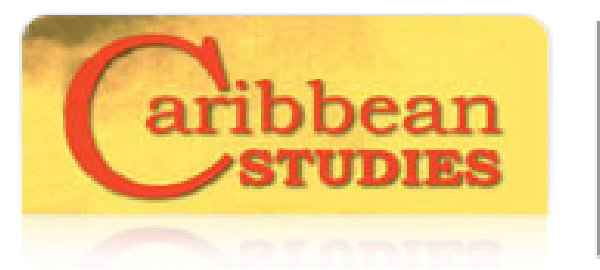

\section{Caribbean Studies}

ISSN: 0008-6533

iec.ics@upr.edu

Instituto de Estudios del Caribe

Puerto Rico

Heartsill Scalley, Tamara

Freshwater Resources in the Insular Caribbean: An Environmental Perspective

Caribbean Studies, vol. 40, núm. 2, julio-diciembre, 2012, pp. 63-93

Instituto de Estudios del Caribe

San Juan, Puerto Rico

Available in: http://www.redalyc.org/articulo.oa?id=39226915004

How to cite

Complete issue

- More information about this article

Journal's homepage in redalyc.org

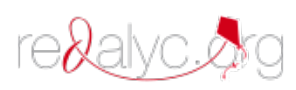

Scientific Information System Network of Scientific Journals from Latin America, the Caribbean, Spain and Portugal Non-profit academic project, developed under the open access initiative 


\title{
FRESHWATER RESOURCES IN THE INSULAR CARIBBEAN: AN ENVIRONMENTAL PERSPECTIVE
}

\author{
Tamara Heartsill Scalley
}

\begin{abstract}
From islands with no permanent flowing streams to those with navigable inland waters, the insular Caribbean contains a great range of conditions regarding the access to freshwater resources. Because of the variation in topography and size, the ability of islands to retain freshwater also varies widely. The usage of freshwater in this region is being led by two major drivers: (1) the demands of basic water needs from an increasing urban population, and (2) those of tourism-based economies that demand water for recreation and aesthetic uses. Formal and informal freshwater management and conservation approaches vary from those being implemented at an individual level based on cultural practices, to those based on government programs. Although most islands have integrated watershed resources practices at some level, economic investment in infrastructure and social governance of water and environment need further evaluation and development. In this overview paper, a description of the natural environment associated to freshwater resources in the insular Caribbean is presented, noting also economic and climatic constraints. Opportunities for improvement in the management of Caribbean freshwater resources are discussed in light of the particular regional environmental context.
\end{abstract}

Keywords: freshwater, watersheds, management, urban, sewage, rural, erosion, consumption, governance, waste water, environment

\section{RESUMEN}

En las islas del Caribe hay una gama amplia de condiciones en torno al acceso al agua, desde islas sin afluentes de ríos permanentes hasta aquellas con ríos navegables. La variedad en tamaño y topografía de las islas también se refleja las diferencias en habilidad de almacenar y manejar recursos de agua de manera local. El uso de recursos de agua dulce y agua potable en esta región está siendo guiado tanto por (1) las necesidades de una población urbana que va en aumento, como por (2) las necesidades de una economía basada en el turismo, donde el consumo de agua incluye tanto usos recreacionales como estéticos. Estrategias de manejo de agua tanto formales como informales están siendo implementadas en toda la región, y éstas van desde prácticas 
culturales individuales hasta programas gubernamentales. Cabe señalar que aunque muchas islas en la región tienen un manejo integrado de los recursos hídricos, aún hay muchos tramos que recorrer en términos de gobernanza social de este recurso y de mayor inversión en infraestructura pues es evidente que hace falta más integración ambiental para un desarrollo efectivo de este recurso. En este manuscrito se presenta a modo de resumen, una descripción del ambiente natural en torno al recurso agua. Se presentan recomendaciones y oportunidades para mejorar el manejo de recursos de agua en el Caribe a la luz de las condiciones particulares del medioambiente de la región.

Palabras clave: agua dulce, cuencas, manejo, urbano, rural, erosión, consumo, gobernanza, aguas residuales, re-uso de agua, ambiente

\section{RÉSUMÉ}

Les îles caribéennes possèdent une grande variété de conditions liées à l'accès aux ressources en eau, y compris celles ayant des rivières asséchées et d'autres disposants de fleuves à naviguer. L'utilisation des ressources en eau douce et potable dans cette région est soumise aux facteurs suivants : 1) les besoins d'une population croissante et ceux de l'industrie agricole intéressée, 2) les exigences d'une économie touristique où la consommation d'eau comprend un usage à des fins de loisirs et esthétiques. Les stratégies de la gestion formelle et informelle de l'eau mises en place dans la région sont basées sur des pratiques individuelles et culturelles de la société et sur des programmes gouvernementaux. Il est important de signaler que plusieurs îles de la région ont déjà une gestion intégrée des ressources hydriques; cependant, long est le chemin à parcourir en ce qui a trait à une gouvernance sociale de ces ressources et à des investissements solides en termes d'infrastructures vers une meilleure intégration de l'environnement et une gestion adéquate de cette ressource. Dans ce manuscrit nous présentons un résumé sur la description de l'environnement naturel autour de la question de l'eau, des recommandations et des opportunités pour améliorer la gestion des ressources en eau dans la Caraïbe en tenant en compte du contexte environnemental particulier de la région.

Mots-clés : eau douce, bassins, gestion, urbain, rural, l'érosion, la gouvernance, la consommation, les eaux usées, réutilisation de l'eau, l'environnement

Received : 30 August 2012 Revision received : 26 November 2012 Accepted : 27 November 2012

\section{Introduction}

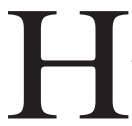

uman subsistence depends entirely on the access to freshwater resources. With this in mind, the islands of the Caribbean currently face unique challenges regarding freshwater resources management, mainly due to changes in the islands' land cover 
and land use patterns over time, in addition to climate change itself. Both land use and land cover have an impact on sediment loads and general water quality, which ultimately affect, not only freshwater resources, but also the countless other systems that are connected to, or otherwise interact with, these resources. These impacts include the salinization of irrigated agricultural lands, increasing urban floods, the contamination of groundwater, severe erosion, loss of infrastructure, and sedimentation in near shore systems, such as coral reefs. Ultimately, the degradation of water resources leads to the loss of biodiversity and ecosystems services, which not only sustain the fauna and flora of these aquatic systems, but are also essential to humans as well.

In this article, a description of the natural environment associated to freshwater resources in the insular Caribbean is presented, taking into account the economic and climatic constraints that characterize some of these islands. Among the observations made regarding the islands' management practices and conservation approaches toward their freshwater resources, it can be said that they vary from those being implemented at an individual level based on cultural practices, to those based on government programs. Although most islands have integrated watershed resources practices at some level, economic investment in infrastructure and social governance of water and environment need further evaluation and development. Finally, opportunities for improvement in the management of Caribbean freshwater resources are discussed in light of the particular regional environmental context.

\section{The Caribbean Water Crisis:}

\section{A Summary of Preliminary Findings}

The fate of human societies, as we know them, may ultimately rest on our access to freshwater supplies. In the Caribbean, island governments and residents have sought different measures to account for their particular water supply situations: While some islands have plenty of freshwater sources, others suffer from dry climates and heavy droughts, among other extreme factors, thus forcing their inhabitants to drastic measures as they struggle to keep up with their populations' freshwater needs.

Although the Caribbean is becoming increasingly urbanized, many rural communities in some islands still do not have easy and continuous access to potable water (e.g., Cuba, Puerto Rico, Jamaica, Trinidad and Tobago). And while these rural communities have an urgent need for clean, potable water delivery, the needs of many urban communities, in contrast, are directly related to the management of sewerage and the overflow of aqueducts (e.g., San Juan metropolitan area in Puerto Rico). 
In most of the Caribbean, a greater investment must be made to build and/or improve the necessary infrastructure for sewage and aqueduct facilities. Current trends in the insular Caribbean seem to be intent on fixing and "patching up" these problems, while ignoring the ever-present chronic aqueduct and sewerage system needs for maintenance, upkeep, expansion and modernization.

Furthermore, the relatively low cost of water in the Caribbean in the recent past has resulted in poorly-maintained infrastructure and water losses that are unaccounted for (nearly $50 \%$ in most of the region): this has been the case in Cuba, the Dominican Republic and Puerto Rico, although many other islands also share this situation. And even though the current costs of served or delivered water have undergone recent price increases in the region (Table 1), island water agencies are still vastly underfunded. The operation and maintenance of hydraulic facilities drive the cost of water delivery, and the current systems everywhere in the Caribbean are barely able to catch up. The government of Cuba, for example, still needs to subsidize its main water agency, the Instituto Nacional de Recursos Hidráulicos (INRH), in spite of implementing charges for the services of potable water and sewerage since1993. There is hope, however, that this new tariff system will eventually lead to a greater valuation of water resources and that the self-financing of Cuba's water agency will be possible. One of the hopes of the tariff-charging system is that these new charges will serve as an incentive to decrease the demand for water and promote a more efficient use.

That said, the prevalent lack of investment in the maintenance of water delivery infrastructures-including wastewater management systems-inevitably leads to a great deal of public health and safety issues, as well as environmental degradation. When water distribution systems are not maintained in a proper and timely manner, it can lead to persistent leaks and the discontinuity and/or interruption of service, which impair the pumping system and interrupt chlorine additions; ultimately, they may cause an accumulation of sediments in pipes and, possibly, the contamination from drainage waters or other polluted sources. This, in turn, affects the domestic storage of water in tanks and cisterns, when they are filled by low-quality water, loaded with sediments.

Moreover, leaky septic tanks, urban water contamination, and effluent from agricultural runoff need to be considered when counting on groundwater resources. The solid waste contamination of soils and subsurface water due to leaching is common. Effective and safe re-usage of gray water and treated sewage must be discussed and encouraged as part of any water resources management plans. The sewage treatment plants with the capacity to redistribute partially-treated waters in order to irrigate ornamental gardens, hotel grounds and golf courses, and to create 
Table 1. Water costs in US Dollars per 1000 US gallons for various Caribbean islands, as reported in water authorities webpages as of July-August 2012. Note that the costs presented reflect only metered and delivered water. These costs do not reflect water bills for the same 1000 US gallon consumption amount as these do not include meter rent, connection fee, energy (fuel or oil) factors, base charges nor sewer fees. Conversions used $3.7854 \mathrm{~m} 3=1000 \mathrm{US} \mathrm{g} ; 1 \mathrm{~m} 3=$ 264 US g; 1 US g $=0.833$ UK g.

\begin{tabular}{|c|c|c|c|c|c|}
\hline Country & 志 & 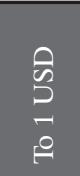 & 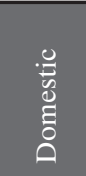 & 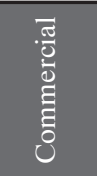 & $\begin{array}{l}\text { Resource for delivered, piped water costs } \\
\text { and tariffs }\end{array}$ \\
\hline Anguilla & $\mathrm{XCD}$ & 2.70 & 12.35 & 37.04 & http://gov.ai/water.php \\
\hline $\begin{array}{l}\text { Antigua \& } \\
\text { Barbuda }\end{array}$ & $\mathrm{XCD}$ & 2.70 & 56.91 & 135.00 & http://www.apua.ag/ \\
\hline Aruba & ANG & 1.78 & 9.61 & 22.78 & $\begin{array}{l}\text { http://www.webaruba.com/en/services/ } \\
\text { water-tariff.html }\end{array}$ \\
\hline Barbados & BDD & 1.98 & 18.56 & 34.88 & $\begin{array}{l}\text { http://barbadoswater.net/ } \\
\text { http://www.bwa.bb/ }\end{array}$ \\
\hline Bonaire & USD & 1.00 & 8.43 & . & $\begin{array}{l}\text { http://webbonaire.com/joomla16/index. } \\
\text { php/nl/thuis/10-productenendiensten/20- } \\
\text { tarieven }\end{array}$ \\
\hline $\begin{array}{l}\text { British Virgin } \\
\text { Islands }\end{array}$ & USD & 1.00 & 12.00 & 25.00 & $\begin{array}{l}\text { http://www.dgo.gov.vg/helpdesk. } \\
\text { php?mhpageid= } 81\end{array}$ \\
\hline Cayman Islands & KID & 0.82 & 19.28 & 22.21 & http://www.waterauthority.ky/ \\
\hline Cuba & CUP & 26.50 & 0.15 & 3.78 & http://www.hidro.cu/documentos.htm \\
\hline Curaçao & NAF & 1.78 & 33.17 & 70.31 & $\begin{array}{l}\text { http://www.aqualectra.com/en/current- } \\
\text { water-and-electricity-rates }\end{array}$ \\
\hline Dominica & $\mathrm{XCD}$ & 2.70 & 58.37 & 98.74 & http://www.dowasco.dm/ \\
\hline $\begin{array}{l}\text { Dominican } \\
\text { Republic }\end{array}$ & DOP & 39.80 & 6.31 & 7.01 & $\begin{array}{l}\text { http://coraasan.gob.do/Informaciones/ } \\
\text { TarifasComerciales/tabid/61/Default.aspx }\end{array}$ \\
\hline Jamaica & JMD & 89.00 & 2.85 & 10.70 & http://www.nwcjamaica.com/RATES.asp \\
\hline Martinique & EUR & 0.78 & 14.26 & . & $\begin{array}{l}\text { http://observatoire-eau-martinique.fr/ } \\
\text { prix-de-leau }\end{array}$ \\
\hline Montserrat & $\mathrm{XCD}$ & 2.70 & 48.60 & 75.60 & $\begin{array}{l}\text { http://www.mul.ms/index.php/customer- } \\
\text { interface/water-subscription-details }\end{array}$ \\
\hline Puerto Rico & USD & 1.00 & 4.16 & 5.78 & $\begin{array}{l}\text { http://www.acueductospr.com/ } \\
\text { MICUENTA/estructura_tarifaria.htm }\end{array}$ \\
\hline $\begin{array}{l}\text { Saba \& St. } \\
\text { Eustatius }\end{array}$ & ANG & 1.78 & 20.99 & 53.82 & $\begin{array}{l}\text { http://www.nvgebe.com/CustomerCare/ } \\
\text { MyBill/FuelClauseandRates.aspx }\end{array}$ \\
\hline
\end{tabular}


Table 1 continued.

\begin{tabular}{|c|c|c|c|c|c|}
\hline Country & $\overline{\bar{E}}$ & $\begin{array}{l}\text { के } \\
? \\
\overrightarrow{0}\end{array}$ & 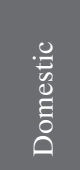 & $\begin{array}{l}\frac{. \pi}{0} \\
\frac{0}{0} \\
\text { ह } \\
0\end{array}$ & $\begin{array}{l}\text { Resource for delivered, piped water costs } \\
\text { and tariffs }\end{array}$ \\
\hline $\begin{array}{l}\text { St Maarten / St } \\
\text { Martin }\end{array}$ & ANG & 1.78 & 20.99 & 53.82 & $\begin{array}{l}\text { http://www.nvgebe.com/CustomerCare/ } \\
\text { MyBill/FuelClauseandRates.aspx }\end{array}$ \\
\hline St. Kitts \& Nevis & $\mathrm{XCD}$ & 2.70 & 21.60 & 54.00 & http://www.cawasa.org/nevis/ \\
\hline $\begin{array}{l}\text { St. Vincent \& } \\
\text { The Grenadines }\end{array}$ & $\mathrm{XCD}$ & 2.70 & 17.55 & 40.50 & $\begin{array}{l}\text { http://www.cwsasvg.com/cwsanewrates. } \\
\text { html }\end{array}$ \\
\hline $\begin{array}{l}\text { Trinidad \& } \\
\text { Tobago }\end{array}$ & TTD & 6.28 & 41.67 & 83.35 & http://www.wasa.gov.tt/, as of 2008 . \\
\hline US Virgin Islands & USD & 1.00 & 19.28 & 21.87 & $\begin{array}{l}\text { http://www.viwapa.vi/Customers/ } \\
\text { RatesFees/ScheduleofFees.aspx }\end{array}$ \\
\hline
\end{tabular}

open holding ponds, are mostly run by private enterprises; however, as the practice becomes more common, it will be of benefit to promote the consistent and frequent monitoring of their practices, for safety.

Various land use practices that involve lack of proper sewage management, especially in suburban areas, have severely deteriorated the quality of the already limited brackish water supplies of some islands (van Sambeek, Eggenkamp and Vissers 2000). For example, in Antigua and Barbuda, as well as in Aruba, rainfall is harvested in small dams for agricultural activities. This practice only provides for a limited local consumption in the immediate areas around the small dams themselves. Although limited in its scale, this collected rainfall is the most costeffective water source for small-scale farmers to use for agriculture due to the high cost of using potable water produced from desalinization or from groundwater pumping. It is precisely because of the inherent economic costs involved in pumping, and the associated environmental risks, that the use of groundwater resources in Cuba is very limited. In the southern coast of Cuba, particularly the cities of Pinar del Río, La Habana, and Sancti Spiritus, there has been a proven incidence of saltwater intrusions into freshwater aquifers. Taking into consideration that most of Cuba's aquifers drain to the sea instead of alluvial valleys and rivers, the potential for saltwater intrusion is greater than in other islands (Cuba 2001). It is thus evident that, in the insular Caribbean, there are pressing needs for the development of effective storage strategies for surface waters and careful groundwater management programs.

Needless to say, as the Caribbean becomes increasingly urbanized, it is necessary to make greater investments, not only in the local water 
delivery infrastructures, but also in the management of storm waters, wastewaters and sewage. Currently, the infrastructure needed to achieve these goals is not present in many islands, with only a few urban and tourism-associated facilities having them; in contrast, many rural and older suburban areas have a failing and insufficient infrastructure to manage the water supply and used waters (Scatena, Ortiz and BlancoLibreros 2008; Cashman, Nurse and John 2010). Failing to properly manage waste waters and rainfall runoff has been proven to exert a direct, negative impact on coastal ecosystems.

Because they are highly valued for their fisheries and as tourism destinations, many Caribbean islands have incorporated, as part of their national agendas, the need to protect and improve coastal resources, including coral reefs. What many island governments need to address is the fact that the health and functionality of coastal and marine ecosystems, in the long run, is highly dependent on, and intrinsically connected to, their freshwater and wastewater management decisions. River landscapes, river edge vegetation (riparian) and the forest cover of headwaters are all important components that must be accounted for in a strategic management plan that would maintain and improve the water quality of streams and rivers, while also significantly reducing the delivery of eroded sediments to coastal and valley areas. Undoubtedly, the effective management of watersheds and their lands will yield positive effects on a larger scale, including with regards to coastal systems.

Beside protecting and managing watersheds and all their encompassing lands, Caribbean islands must also incorporate natural rainwater accumulation and freshwater recharge into their water resources management plans. If natural catchment areas were maintained to facilitate proper rainwater recharge, other Caribbean islands would probably develop a greater usage of their groundwater resources. As occurs elsewhere, rainfall could have the potential to effectively recharge freshwater and maintain brackish groundwater in Aruba, Curaçao and Bonaire, rather than resorting only to the costly process of desalinization, which not only places an economic burden on these islands, but it also comes at a great environmental cost.

Caribbean islands should also consider investing in alternative energy sources for the treatment and purification of water (like solar water treatment plants), and on protecting lands to serve as alternative storage sites for freshwater. Desalinization is currently too expensive and might exclude users such as small-scale and subsistence farmers. Water conservation practices must be researched, tested, and implemented to improve the agricultural and tourism practices of the region.

Another fundamental pillar that requires continued investment is providing accessible education opportunities to implement Integrated 
Water Resources Management (e.g., Puerto Rico's water bill provides conservation tips and reports on quality, Cuba's outreach materials on decreasing water demand, St. Lucia's exchange of farmers' livelihoods from land-eroding ganja-growing practices to sustainable flower farming), with the purpose of promoting practices and cultural awareness toward best practices of water and watershed management (Cuba 2001; John 2006; Scatena, Ortiz and Blanco-Libreros 2008). These education efforts should contemplate agricultural practices to minimize erosion and protect aquifer recharge areas (John and Firth 2005). Because water access for all users in many islands cannot be guaranteed yearround, water conservation and reuse initiatives must be a priority in the Caribbean agenda as part of Integrated Water Resources Management (Box 1).

As an additional note, in teaching water resources management

Box 1. International water resources; Concepts and principles

Adapted from:

$<$ http://www.gwp.org/The-Challenge/What-is-IWRM/Dublin-Rio-Principles/>

\section{Integrated Water Resources Management (IWRM):}

The formal concept of integrating water for people, water for food, water for nature, and water for industry and other uses. The Technical Committee of the Global Water Partnership (GWP) defines Integrated Water Resources Management (IWRM) as a process which promotes the coordinated development and management of water, land and related resources in order to maximize economic and social welfare in an equitable manner without compromising the sustainability of vital ecosystems and the environment.

There are various principles and approaches relevant to IWRM, each having suitable application. However, IWRM is primarily guided by the Dublin Principles that emerged from the United Nations Conference on Environment and Development (UNCED) in Rio de Janeiro in 1992.

\section{The Dublin Water Principles (1992)}

(i) Fresh water is a finite and vulnerable resource, essential to sustain life, development and the environment.

(ii) Water development and management should be based on a participatory approach, involving users, planners and policy-makers at all levels.

(iii) Women play a central role in the provision, management and safeguarding of water.

(iv) Water has an economic value in all its competing uses and should be recognized as an economic good.

IWRM recognizes that water is an integral part of the ecosystem, a natural resource, and a social and economic good, whose quantity and quality determine the nature of its utilization. It is a comprehensive approach to the development and management of water, addressing its management both as a resource and the framework for provision of water services. 
and conservation to younger generations, educational initiatives must transmit knowledge regarding "Mountain Ridge to Coral Reef" processes and the connection of watershed lands to water resources (Gomi, Sidle and Richardson 2009). Becoming aware of the connection between mountains and coastal ecosystems, not only helps us to understand where freshwater comes from and how it reaches our homes, but it also teaches us about the importance of using our freshwater sources sustainably. If freshwater is perceived as an unlimited resource, it will be wasted, whereas acknowledging water as a vital resource that must be used wisely directly leads to conservation of the resource (Corral-Verdugo, Bechtel and Fraijo-Sing 2003).

To summarize: All in all, it is imperative for all Caribbean islands to improve management strategies regarding freshwater resources, taking into account the links between changes in land cover, consumption trends, and economic growth (Ortiz-Zayas and Scatena 2004; Cashman and Daniel 2008). In doing so, Caribbean freshwater resource management strategies must adapt to the development and modification of landscapes, as changes in land cover are concomitant to changes in freshwater catchment and recharge areas (John and Firth 2005).

\section{Freshwater in the Caribbean: Where Does It Come From?}

Caribbean islands span a great range of conditions in terms of access to freshwater resources. Some islands have no permanent flowing streams, while others have navigable inland waters. Furthermore, there are many intermittent or seasonal streams and rivers in the insular Caribbean, partly because of the geological nature of the islands, many of which have porous karst substrates, and also due to the effect of seasonal precipitation patterns. For most Caribbean islands, rainfall seasonality means a relatively dry period from December to March (Taylor et al. this issue). It is important to note that over the last century, annual precipitation has declined in the Caribbean, and although occasional intense rainfall events have increased, seasonal drought conditions remain common (Litner et al. 2012; Taylor et al. this issue). As changes in rainfall seasonality continue to take place in the Caribbean, so do changes in the region's land cover and expansion of urbanized areas, all of which, in turn, affect freshwater resources.

In terms of water resources capacity, the islands of Cuba, Hispaniola, Jamaica, and Puerto Rico, as opposed to smaller islands, may potentially store larger amounts of freshwater in constructed dammed reservoirs, but they also have many constraints when it comes to distributing water and maintaining the delivery infrastructure. In the islands with higher elevation ranges (i.e. taller mountains), there are relatively 
more water resources because mountains can "trap" rain clouds and, thus, retain localized rain events of orographic origin (Box 2). The rain that is "trapped" and slowly released in the mountains contributes to the formation of various native vegetation types that serve as functional water sponges: Wetlands. These wetland ecosystems include those that occur in the mountainous terrain and peaks (as various types of cloud forests), those in sloped valleys and, most notably, the wetlands in coastal areas (mangroves and other brackish water vegetation types) that help to retain and recharge freshwater in the islands' landscape.

On the other hand, islands with restricted elevation ranges lack orographic rainfall and, therefore, depend greatly on seasonal precipitation and weather events. These smaller and relatively flat islandsincluding Anguilla, the British and US Virgin Islands, Bahamas, the

\section{Box 2. Water resources, terms and definitions.}

Adapted from: <water.epa.gov>, A dictionary of technical and legal terms related to drinking water.

Catchment or Watershed: The area of land that collects, drains, and distributes water to a stream or river system. This includes both above ground and below ground area.

Orographic precipitation: In the Caribbean, it occurs when warm humid air masses that come from the ocean reach the windward slopes of mountains. As the humid air masses are forced to rise up along the mountain they lower their temperatures and as the air mass cools the water vapor they contain condenses into clouds and localized rainfall occurs.

Wetland: Any type of landform that includes both water that is flowing or standing, either inundated or saturated, and may consist of different vegetation types. Some of the wetland vegetation types are mangrove forests, palm forests, herbaceous marshes, and elfin cloud forests.

Intermittent stream: A stream that will cease to flow seasonally when its water table drops below the stream bed or below the ground.

Ephemeral stream: A stream that is not dependent on a water table or water below ground, and only flows based on the amount of rainfall collected, or from overland flow and runoff in its watershed.

Groundwater: Any type of water that occurs and is in storage underground.

Aquifer: An underground rock formation that can store water. The rock material is porous, to hold the water, and may be composed of sands, soils or gravels. Aquifers may also drain to wells or springs. It may contain water with different amounts of total dissolved solids (TDS, this includes salts and minerals).

\section{Water types:}

Brine: Water that has a greater concentration of TDS than ocean water.

Saline: Water with less TDS than brine, may be similar to ocean water.

Brackish: A mix of fresh and saline, water with less TDS than ocean water.

Freshwater: The least amount of TDS, considered drinkable. 
Cayman Islands, Barbados, St. Martin/Sint Maarten, Aruba, Curaçao and Bonaire-not only have naturally limited land areas for water storage, but they also have a drier landscape as a natural starting point condition. Fortunately, seasonal rainfall events do leave a mark on the landscape, with the capacity to recharge stream systems, aquifers and groundwater resources.

In these smaller and flatter islands, the naturally-occurring vegetation types that contribute most to freshwater retention and subsurface water recharge are riparian zones and various types of wetlands, both in the islands' interior zones and in coastal areas. The dry forests, scrub forests and seasonally dry forest types are a more common vegetation type in islands with less elevation. In these islands, the seasonal rains have sculpted the landscape and formed seasonal watercourses that lead waters to recharge aquifers, move water along the terrain and eventually reach the coast.

Dry stream beds are another important feature to take into account when considering water resources management strategies. Although they are referred to by many names-in both Montserrat and St. Kitts and Nevis, they are known as ghauts, in Barbados they are gullies, while in the US and British Virgin Islands, they are termed guts or ghuts-these intermittently flowing, or ephemeral, watercourses are seasonally dry streams and rivers that play an important role in Caribbean hydrological systems.

For millennia, the people in Caribbean islands have used these ghuts as community meeting places and as landscape reference points. In addition, dry streambeds are often used as trails and roadways, thus adding to their social value (Gardner, Henry and Thomas 2008). As movement corridors for people, ghuts often provide a more comfortable, shaded and protected area to move about in rural areas. Nevertheless, the ecological values of dry streams are often overlooked. The vegetation areas around ghuts often contain unique herbs, vines and trees not present in to the rest of the drier landscape. This is partly because ghuts are natural sinks for leaves, seeds and sediments that collect from upslope areas and eventually accumulate there from the surrounding terrain (Gardner, Henry and Thomas 2008).

Because dry streams receive water from the immediate catchment areas, but only flow seasonally, they can be cooler in temperature and retain more humidity. The stream channel can have subsurface water that may flow or accumulate below the ground. In many cases, another value of land and vegetation areas around ghuts is that they may often be the only remaining sites in a landscape where the land has not been completely converted to agriculture or other land uses that may have otherwise modified native land cover. 
The vegetation along the ghuts and the physical structure of the dry watercourse itself can serve as spaces for the migration and movement of fauna, including birds, butterflies and other invertebrates (Steward et al. 2012). In many dry rivers, fauna continues to use the dry river bed after water flow has disappeared. After heavy rains and floods, it is in these ghuts where plant materials such as leaves, fruits and flowers, can gather, accumulate, and later serve as food sources for invertebrates, birds, lizards and snakes, among other fauna. In ghuts with vegetation and a natural stream channel, plant materials and sediments can remain, and they are not delivered in bulk to estuaries and coastal areas, thus minimizing sedimentation in other ecosystems.

Dry river beds that are protected with riparian vegetation provide important services, including the accumulation of sediments and other plant materials from the catchment lands. In this way, dry rivers with riparian vegetation contribute to restraining erosion from the surrounding landscape and minimizing sediment delivery to coastal zones. The riparian zone and watercourse itself will accumulate terrestrial materials that would otherwise directly reach reservoirs, estuaries, coral reefs and coastal fishing areas and increase turbidity and sedimentation, lowering water quality and negatively affecting coastal resources.

Finally, although during dry periods there may appear to be isolated pools of water in the landscape, these maybe seasonally connected to other stream and river segments. In Curaçao, there are only a few seasonally-connected streams; however, it is in those streams where native fish and shrimp fauna still exist. If these intermittent stream channels are destroyed, their associated plants and animals have no other place to live in the landscape (Debrot and van Soest 2001; Debrot 2003).

In order to guarantee the continued access to freshwater resources, it is important to understand that stream and river systems in the islands are permanently undergoing natural changes. Stream seasonality-or the changes that occur in streams over the seasons-influences freshwater availability, and understanding this dynamic component of stream seasonality leads to better management decisions at the landscape and watershed scale. For example, factors such as the width, length and connectivity to other stream segments of a river system depend on the season in which they are observed. Therefore, any decisions about land management and changes in land uses must take into account the transient and intermittent state of streams and ghuts. And while springs, wells, and seasonal pools or isolated pools of water are considered a part of local culture and history in the islands, and therefore occasionally featured in local maps, the intermittent or seasonally dry stream channels are hardly ever taken into account, thus limiting the level of awareness regarding their ecological importance. In order for management and 
conservation programs to be effective in Caribbean watersheds, dry streams must be considered and included in local maps and government guidelines. Failure to do so can have negative consequences for people and water resources management. Clearly identified channels of waterflow in the landscape can help divert and distribute water accumulation from intense rainfall events and, therefore, aid in the management of waters that would be contributing to floods. Clearly identified water-flow channels in the landscape also provide better guidance for the recharge of aquifers, the health of groundwater resources, and for all the hydrologic systems that connect downstream (Steward et al. 2012).

\section{A Changing Caribbean Landscape: Urban Land Use and its Effects on Water Resources}

In the insular Caribbean, the changes to the landscape that deliver most sediment to the coastal zones are unpaved roads, because they create erosion gullies due to the lack of culverts to manage water flow (Ramos-Scharrón and MacDonald 2007). In addition, impervious surfaces in road networks also inflict additional damage by increasing the amount of sediment and particle-filled waters that are being delivered to downstream systems and coastal areas, because they do not allow sediments to settle and accumulate as they would in natural substrate drainages (Thorn et al. 2001).

In our efforts to channelize the natural flow of water systems within our cities and urban settings-either by using direct channels, or culverts, as well with any paved impervious surface-, we are increasing the speed of water as it moves through the urban system, while allowing for the accumulation of larger quantities of water (Figure 1). Peak water flows in urban environments are greater than those of non-urban areas, or vegetated areas. In addition, paved urban areas are subject to additional "peak flow" events, so that there are a larger number of floods with a greater intensity (Cashman, Nurse and John 2010).

Meanwhile, by replacing areas such as forests, pastures and other ground cover types with built infrastructure and roads, we are also increasing the amount of impervious surfaces in the landscape. Impervious or impermeable surfaces such as asphalt and cement, which are present in all built-up and urbanized areas, not only affect water flow in various ways, but they also impact freshwater systems such as catchment areas, streams, rivers, and estuaries. As natural ground cover is replaced with impervious surfaces, the direction and quantity of water flowing is changed, the drainage of overland water flow is concentrated and increased, while the water-holding and recharge capacities of soils are severely decreased or totally eliminated. 
Figure 1. Schematic of duration and amount of water discharge in relation to catchment (watershed) land cover/land use. Note differences in peak flow intensity and time lag. Adapted from Beaulac and Reckhow 1982.

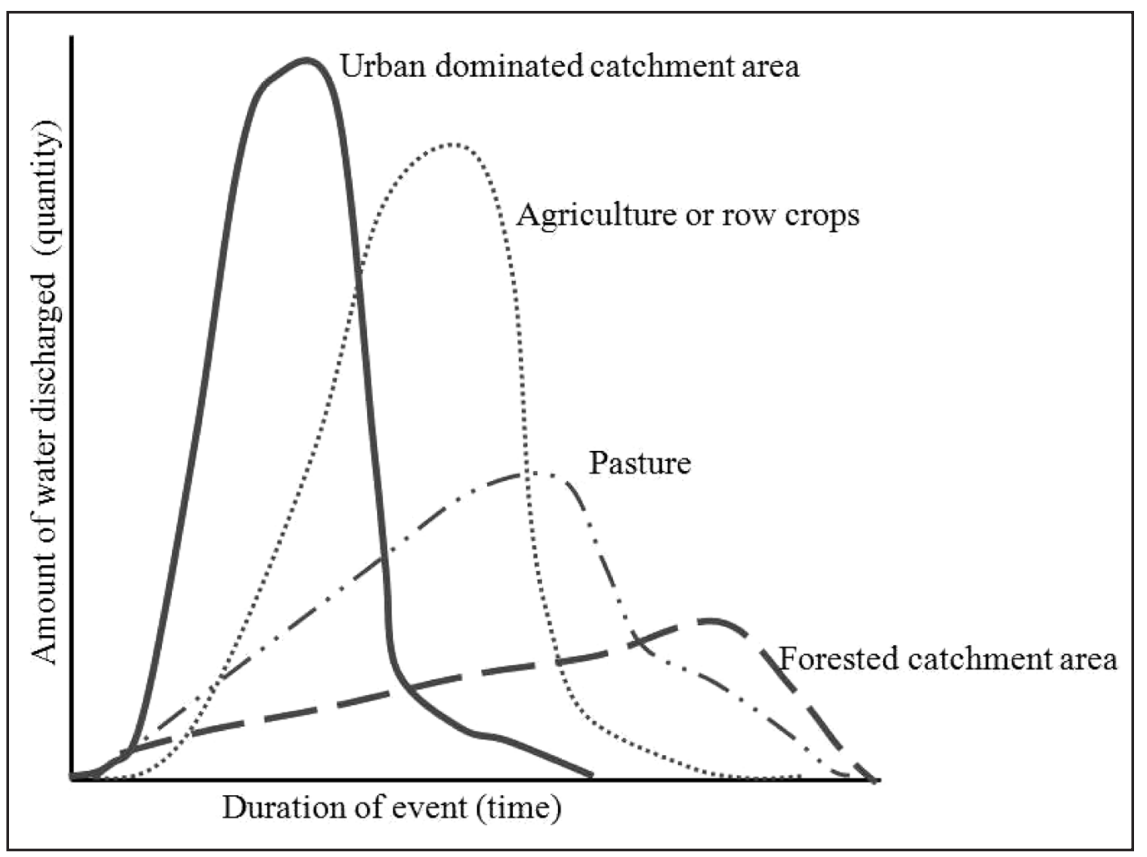

Oral history accounts from the US Virgin Islands, Vieques and the southwest of Puerto Rico mention various local water sources, including springs and intermittent streams that have dried out completely in the last decades, presumably due to changes in land cover that altered soil water recharge capacity (Zack and Larsen 1994).

\section{From the Ground to the Surface: The High Cost of Making Up for Freshwater Shortages}

Many islands in the Caribbean region do not have surface freshwater as a constant resource. One such case is The Bahamas, where freshwater resources are derived mostly from groundwaters, which occur in less than $5 \%$ of the land (Cant and Weech 1986). The groundwater within the limestone aquifers contains both brackish water and freshwater lenses floating on top, also known as Ghyzen-Hertzberg lenses. ${ }^{1}$ The rainwater that falls in these islands percolates through the porous limestone surface, and does not accumulate in the surface to form flowing waters, but rather recharges groundwater sources such as these aquifers. However, due to the increasing expansion of urban infrastructure, the impermeable 
surfaces of concrete, asphalt and other construction materials transport rainwater faster, taking it directly out to sea without properly recharging groundwater resources. Therefore, a key management need is to delineate and map the watersheds that form these groundwater systems, and to clearly define where the recharge areas for these groundwater resources are located in the landscape.

The Cayman Islands, like The Bahamas, also have restricted freshwater resources. Their groundwater resources are also limited to thin, irregularly-shaped freshwater lenses floating on top of denser brackish and saline water (Ng, Jones and Beswick 1992). It is crucial in islands like these to carefully manage pumping and extraction rates to maximize this freshwater resource. All water-pumping activities are monitored in the Cayman Islands and these demonstrate that, even at low pumping rates, saline intrusions and increased water salinity can occur due to the small size, limited storage capacity, and thin and irregular nature of the freshwater lenses (Ng, Jones and Beswick 1992). In islands without surface freshwater there are brackish and saline water lagoons associated to wetlands in coastal zones that are part of the natural groundwater systems, and serve as the source water for desalination.

Groundwater is also an important resource in Antigua and Barbuda, as streams and rivers only flow intermittently. Their streams and rivers may flow for only a couple of months, during and after the rainy season (Cooper and Bowen 2001). To maximize the seasonal freshwater resources from rainfall, the people of Antigua and Barbuda have placed small dams on all major streams and rivers. In these intermittent stream systems, there are shallow reservoirs that store freshwater. However, the water in these small reservoirs is often completely consumed during the dry season. Because they are seasonal resources, these reservoirs are unable to supply all water needs. For this reason, the water supply is supplemented by groundwater that is pumped from some 50 active wells. Since the 1980s, various drought periods have consumed and emptied reservoirs, and led to the depletion of available groundwater. In addition, these drought periods have put stress on, and often maxed out, Antigua and Barbuda's additional water resources that are supplied by various active desalinization plants.

Currently, most of the water that is served in Antigua and Barbuda comes from desalinization, followed by surface reservoirs and, lastly, from pumping groundwater resources. There are various costs involved in using groundwater, including the economic cost of pumping, as well as the environmental cost of overexploitation, especially during drought periods, thus exacerbating the situation with saline intrusions. At an additional economic cost, during crisis drought periods, water for domestic consumption (mainly drinking) has been brought in on barges from 
neighboring islands. Government agencies in Antigua and Barbuda, The Bahamas, and St. Vincent and the Grenadines have all resorted to this practice (Cooper and Bowen 2001).

\section{Honing the Local Freshwater Supply: Local and Regional Water Reservoirs}

While many Caribbean islands do have permanently flowing surface waters, because of their limited area extent, abrupt topography, and particular geology there are very few large freshwater reservoirs in the region. There are some exceptions, as there are some large reservoirs in Cuba, Hispaniola, Jamaica, Puerto Rico, and moderately sized ones in other islands such as St. Lucia and Dominica (Geoghegan 2002). However, often when abundant rain events occur, or there are consistently rainy years, the freshwater resource cannot effectively be retained in reservoirs. During intense rainfall, there is an overflow of existing reservoirs and dams because most dammed reservoirs are heavily silted and, therefore, have decreased their water holding capacity. Consequently, freshwater resources are delivered immediately to the sea and not efficiently stored during many intense rainfall events.

To enhance local supplies and partially mitigate the need for freshwater storage, in many Caribbean islands it is customary for households to collect rainwater in cisterns. In some islands, laws have been instituted that require that all new domestic buildings have systems to collect and store "roof top" rainwater, as in the US Virgin Islands and Barbados (CEHI 2009b). Many households in the insular Caribbean had already integrated this practice to their dwelling structures and, as such, depended on rooftop water during times of drought and planned water shortages alike.

Other reservoir or independent type strategies for assuring access to water in isolated communities and rural areas are "private aqueducts," community-managed aqueducts, or other arrangements. Although many think that in highly urbanized Puerto Rico all water is served by the centralized government water authority; the Autoridad de Acueductos y Alcantarillados (AAA), it is estimated that close to $7 \%$ of the population is supplied water by independent, community-managed systems (Minnigh and Ramírez Toro 2001). These systems include a large range of water supply strategies from pipes directly placed in mountain streams, to homemade dams and well water pumping. These communities are, in many cases, creating their own water delivery systems, as they would not have been reached and served by the AAA. In other cases, these systems supplement existing deficient water delivery services, or as in Trinidad, serve communities who used to have water delivery but then were 
abandoned and ignored after system failures (Scheniederman and Reddock 2004). Usually, these systems are the only reliable source of water for communities that may not be served at all due to the topography of their location, or the infrastructure only serves water in an interrupted and intermittent unreliable, almost nonexistent schedule (Minnigh and Ramírez Toro 2001).

There can be private or government incentives for establishing community aqueducts, reservoirs and urban rooftop water storage systems, and these are all alternatives currently in practice in many Caribbean islands (CEHI 2009). Although they represent viable options that supplement or substitute piped water service, careful attention must be given by local institutions to ensure continued support (by facilitating monitoring, training and education) so that the water served in these systems can be effectively and safely managed. In some cases, communities prefer to be completely separated from centralized and regional piped water delivery services due to past and current failures of systems, and they believe that maintaining separate control of their water delivery infrastructure guarantees access to at least some water (Minnigh and Ramírez Toro 2001). In addition, they have control over their water treatment and water safety; hence the community's health is in their own hands.

\section{Water for Agriculture: Using and Reusing}

The aim of farmers and the agricultural sector is not to consume water for the sake of it, but to have the ability to raise livestock and to grow fruits and vegetables in a profitable way, so as to make a living and provide sustenance (Gleick 2003). A farmer's water quality and delivery needs are very different from those of domestic users and many industries, which need constant access to purified and potable water. Improvement in crops per unit of water consumed can be achieved via many strategies, including relatively simple adjustments as land contouring, altering the timing and length of drip irrigation, and water storage and reuse strategies, which are all very cost-effective, thus allowing farmers to grow more, and more efficiently (Falkenmark, Lundqvist and Widstrand 1989; Gleick 2003).

Although small-scale dams and reservoirs aid in improving access to water for agricultural and domestic uses, if not constructed and executed properly, they may come with high environmental costs (March et al. 2003; Baisre and Arboleya 2006; Greathouse, Pringle, and Holmquist 2006). Dams affect the shape of rivers that are located downstream from them, and alter the natural process of sediment-delivery in alluvial and coastal valleys that are crucial to maintain soil fertility and agricultural production. In addition, dams sever the natural ecological connection 
between mountain areas (upstream) and coastal areas (downstream). Most aquatic species in the insular Caribbean have life cycles that depend on the free movement between the freshwaters of mountain streams and the brackish and salt waters of the estuaries and coast. Unfortunately, in many parts of the insular Caribbean, stream and river segments are still being dammed and channelized, and water extraction consumes most of their flow: Thus, natural or unaltered river flows are rare. In most of the insular Caribbean the environment's right to water (Box 3 ) is still hardly discussed or mentioned at all within formal development plans with few notable exceptions (e.g., Anguilla 2001; Geoghegan 2002; Scatena 2004; DRNA-PR 2008).

In the Dominican Republic, for example, dams were built during the 1970 to 1980 s to satisfy the needs for the irrigation of agricultural lands, energy production, and as reservoirs for human water consumption (De León 2012). Currently, new dams to provide water for irrigation have been built, and additional plans are in place to create at least four more dams for energy production. However, there has been little to no talk on building infrastructure for wastewater treatment, residual and wastewater management, or water reuse delivery systems, which would alleviate many, if not all, of the agricultural sector's water needs (De León 2012). In this way, the Dominican Republic is not different from many other Caribbean islands, which hardly invest funds on waste water management systems (Brown, Geoghegan and Renard 2007).

Furthermore, failing to properly manage waste water and residual agricultural waters severely endangers existing groundwater resources. In Puerto Rico, for example, industrial and toxic wastes threaten both

\section{Box 3. Environmental flows, a better minimum flow standard.}

Adapted from: Scatena 2004.

How are decisions made as to how much and how often

to divert or pump water from a river?

Who are the users for whom waters are diverted?

Who are the stakeholders that consume river water?

Environmental flow and minimum flow standards are the way to fully and sustainably address these questions, with specific considerations for particular streams and rivers. These flow standards are defined by a combination of conditions and metrics, not just one arbitrary measure. For a specific stream or river these standards are established with both quantitative and qualitative data that include, but are not limited to, historic water discharge measurements, stream channel morphology (shape, slope, substrate bottom composition), water quality, needs of aquatic species, needs of riparian fauna and vegetation, and the needs of all users and stakeholders for the particular stream or complete watershed area. To establish effective environmental flow standards there must be investment, contribution and participation from local governments, communities and all freshwater stakeholders. 
surface waters and ground waters, in addition to the more common agricultural fertilizers, pesticides and herbicides (Hunter and Arbona 1995). Meanwhile, in Aruba, Curaçao, and Bonaire, sewage and agricultural irrigation waters, as well as seawater, have leaked into the ground in areas with high population density and agriculture (van Sambeek, Eggenkamp and Vissers 2000). A monitoring system for the chemical composition of groundwater was established during the1980s in all three islands, but it was stopped after less than 20 years in Aruba and Bonaire; it currently continues only in Curaçao. In Curaçao and Bonaire, very high concentrations of nitrates, well above $25 \mathrm{mg} / \mathrm{l}$, are found in soils and groundwaters (van Sambeek, Eggenkamp and Vissers 2000). Nitrates are related to agriculture and livestock contamination and can cause severe health problems. Pollution-derived sulphate and potassium are also at high levels within the groundwater, and this is linked to leakage from raw sewage, sewage waters and open cesspits.

\section{Desalinization: A Costly Strategy for Fulfilling Water Demands}

Desalinization is a costly process that involves removing salt and other minerals from saltwater. Some Caribbean islands have resorted to this practice, as a means to make up for their limited freshwater sources. However, not only is desalinization expensive, but there are still many issues that are not understood as related to the proper disposal of mineral and metal by-products of the process (Voutchkov 2011; Gleick 2006).

Islands such as Aruba, Curaçao and Bonaire have turned to ocean water desalinization in order to meet their domestic piped water needs. Consequently, the infrastructure and management of used waters and waste waters have been left behind. In Antigua and Barbuda, where drought periods have occurred with certain frequency since the 1980s, the islands have sought to complement their freshwater resources through various active desalinization plants. Although there are at least two governmental desalinization plants, the private manufacturing and tourism sector also owns and operates many small-scale desalinization plants in these islands (Cooper and Bowen 2001). Even Cuba, with potentially ample water resources, has had to supplement surface water delivery to areas heavily used for tourism with desalinized water via costly investments and partnerships. Various desalinization plants (reverse osmosis) have been established in Cuba during the last decades (Cuba 2001), particularly in areas where surface water delivery was not possible due to landscape conditions, which also correspond to cays and peninsulas that are tourism centers. 


\section{Water During the Dry Seasons: Planning Ahead}

In order to plan ahead for water shortage situations, many islands have set water usage priorities for public sectors in order to effectively manage this resource during drought periods. For example, in Cuba, the National Water Resources Institute (INRH) has established the following order of priorities: Domestic population uses, food industry, agro-fisheries, general industry, root vegetables and greens, sugar cane, rice, other agricultural uses, and other uses such as tourism (Cuba 2001). Similar lists of priorities exist for most other Caribbean islands, and although this does not eliminate the demand for resources, it helps to plan for water availability.

For most of the insular Caribbean, irrigation is concentrated in January to April, the dry season. But, of irrigated lands, more than a million hectares are affected by increased soil salinity due to the usage of water from wells with elevated salinity (Cuba 2001; FAO 2012). Other causes of increased soil salinity include obstructions to natural drainage and improper water distribution systems. Over the past twenty years, the agricultural lands in the eastern provinces of Cuba, such as Guantánamo, Granma and Holguín, have been affected by drainage problems that have caused increased soil salinity. Planning for water consumption demands needs to incorporate improved irrigation and more efficient technologies that will decrease damages to agricultural soils and watersheds. Furthermore, Caribbean islands tourism should, by default, implement basic practices for responsible water management in order to account for their seasonally dry environments, such as reusing gray waters, treating sewage, and collecting rainfall (Young-George, Mahon and Cumberbatch 2007). Moreover, an appropriate management of groundwater resources includes the identification of recharge areas for subsurface waters at local scales. One place where such initiatives are being implemented is Barbados, which is classified as one of the world's top 15 most water-scarce countries, based on a renewable water resource availability of 390 cubic meters per person per year (CEHI 2009b; Johnson and Mwansa 2007). Barbados has proposed a water augmentation strategy that includes managing not only potable water usage, but also regulating non-potable water usage and distribution. This strategy expects to address the demands for agricultural water for irrigation, which is currently the greatest strain on Barbados' potable water supply. Exploring new initiatives to reuse gray waters in agriculture and tourism, such as the example in Barbados, must be continuously incentivized and eventually mandated. 


\section{Water for Tourism: Meeting a Greater Demand for Local Water}

In the insular Caribbean, the dry season is the period of greatest demand for the irrigation of agricultural lands, and it coincides with increased tourism. Although tourism is the main component of many Caribbean economies and it contributes to economic growth, it also consumes a great deal of natural resources and its activities do not tread lightly on local environments.

Many natural areas and parks around the world have set a "carrying capacity" ${ }^{2}$ standard by limiting the number of visitors per day, per month or per season. Some Caribbean islands may need to consider this approach, or a similar option to maintain their freshwater resources and meet the needs of the various consumers at seasonal scales. There should not be a competition among the agricultural sector, domestic users and the tourism sector in terms of water supply and infrastructure needs. Even though the tourism sector is an important part of the economyand sometimes the main source of income-for many Caribbean islands, water resource development should not by guided solely by the tourism sector's needs (Young-George, Mahon and Cumberbatch 2007). The tourism sector should not have political leverage or preferential treatment when it comes to its share of water resources consumption and mandated management of waste waters.

Tourists must be aware of the Caribbean water scarcity situation and local water resources management practices, so that tourism is maintained as a sustainable enterprise with healthy practices. As a fair participant to the local economies, the tourism sector must contribute the full cost of resource consumption and the associated environmental impacts (Geoghegan et al. 2003). The needs of a self-sustaining environment along with the needs of domestic users (including agriculture and industry) should drive the development of water resources that integrate all participants in its governance (Box 4).

For example, let's take a look at the case of Anguilla. As the Government of Anguilla (2005) has come identify, a major issue in the development of the country is the non-integration of environment into tourism. Tourism in Anguilla, as in many Caribbean islands, is the main source of economic growth, income and improved living standards. Consequently, the tourism sector is one of the main consumers of natural resources and its activities have great impact on the environment. Currently, the Government of Anguilla is planning to implement greater communication as a general practice on all environmental management practices and strategies. This includes broader participation in the design, implementation and decision-making processes (Box 5). Before the consultation and participation with a broad base of stakeholders is conducted, an overall 
Box 4. Water Governance; Definitions and principles

Adapted from Peter Rogers, 2002.

\section{Water Governance}

The notion of governance, when applied to water refers to the capability of a social system to mobilize energies, in a coherent manner, for the sustainable development of water resources. The notion includes the ability to design public policies (and mobilize social resources in support of them) which are socially accepted, which have as their goal the sustainable development and use of water resources, and to make their implementation effective by the different actors/stakeholders involved in the process. An adequate level of governance performance is one aspect of the development of water resources, other aspects being the technical, infrastructure/physical and the economic.

Governance of water is a subset of the more general issue of a society's creation of physi$\mathrm{cal}$ and institutional infrastructure, and of the still more general issue of social cooperation, which reminds us of the problems of defining who are the stakeholders, communication among stakeholders, the allocating of contributions and outputs, and the creation of institutions.

Governance is a more inclusive concept than government per se; it definitely embraces the relationship between a society and its government.

Therefore, water governance refers to the range of political, social, economic, and administrative systems that are in place to allocate, develop and manage water resources and the delivery of water services for a society.

sense of awareness regarding environmental issues must be communicated among the sectors involved, in addition to establishing education initiatives. Other goals proposed by the Government of Anguilla in relation to freshwater resources include the following: 1) an approved and finalized land use plan, 2) waste and effluent management standards, and 3 ) to have databases on potable and recreational waters. Anguilla's current awareness of a disconnection between tourism activity and environmental consequences is a significant step into better environmental management practices.

In the case of Grenada, island residents have recently become increasingly concerned about their water quality and the lack of accessibility to freshwater during the dry season, particularly as a result of increases in water demands from the construction of infrastructure related to tourism development and irrigated agriculture (Geoghegan et al. 2003). The Government of Grenada has responded by working together with the separate agencies that are responsible for water-related systems: the Forests and National Parks Department and the National Water and Sewage Authority. Commitment and work among these agencies has been facilitated thanks to the establishment of a national initiative on watershed management. Farmers and domestic users of water account for twice as much consumption as non-domestic users, which 
include the commercial and industrial sectors, as well as hotels, schools and public service (Geoghegan et al. 2003). In this case, the inclusion of farmers in the same domestic water provision system may not be favorable, considering that drinking quality, potable water, is not necessarily the best suited for agricultural needs. Although current metered water tariffs in Grenada provide funds to operate the National Water and Sewage Authority, and metered water provisioning has been positively received by most of the population, many small-scale farmers have been forced out of business because they can't afford the costs of metered potable drinking water for use in farmlands. Gray waters and partiallytreated waters may be substituted in many cases for certain agricultural crops, but the system infrastructure to deliver these types of water is currently not in place (Cashman and Ashley 2008). As in most other Caribbean islands, the maintenance of water delivery infrastructure in Grenada depends on foreign investments and loans. These foreign investments are usually destined to develop new potable domestic and commercial water delivery, and not for the repair of existing systems, or for water reuse and waste water systems, which are lagging behind compared to new infrastructure developments.

\section{Water for Our People: Domestic Consumption Demands}

Often times, conservation measures are applied in response to government regulations or conservation programs. Usually, public acceptance is limited despite the economic benefits, especially in situations when water shortages are not experienced directly due to the buffering from domestic cisterns, reservoirs, or tanks (CANARI 2005; Farrell, Moseley and Nurse 2007). For example, in Cuba, the agency responsible for the functioning of water delivery systems is also chartered with implementing water reuse and conservation strategies (Cuba 2001). All industries in Cuba are assessed under water reuse and conservation indicators, and, thus, there have been advances in the basic industries and agriculture sectors. In urban areas, the reuse of residual waters has been possible through investments on infrastructure such as holding reservoirs and lagoons for oxidation, which, in some cases, provide irrigation for gardens and grounds in tourist areas. The reuse of irrigation waters in the agricultural sector, particularly sugar, has provided important economic and conservation gains, as the waters contain reusable fertilizers and other liquid residuals from the sugar cane processing. These scenarios should be evaluated for applicability and considered in the near future for all Caribbean islands, since many share similar needs (Johnson and Mwansa 2007).

It is clear that water conservation activities are important to 
maintain and engage all stakeholders in sustainable lifestyles. However, what seems to not remain clear sometimes is how to translate these water conservation activities into actions, at the hands of all water consumers and decision-makers. In terms of conservation attitudes by the people, in Cuba, for example, educational campaigns have aimed to give specific and daily-life examples that easily engage the public in these conservation activities, by making them seem feasible and easy to follow. Only when we are able to provide easy and clear examples of types of behaviors and actions, do water conservation behaviors occur (Corral-Verdugo, Bechtel and Fraijo-Sing 2003). In Cuba, outreach materials from the PAURA program ${ }^{3}$ have daily life examples and simple illustrations include how-to instructions for fixing a dripping faucet, and how much water is wasted/lost depending on the size of the dripping drop (e.g., per diameter of tube where the drop originates, following an estimate of how many gallons are lost in a day).

In Grenada, like in many other parts of the Caribbean, rural water users live in the forested headwaters where water is produced, but are continuously subjected to water rationing and interrupted services. Rural waters users are usually aware of the connections between forests and streams in their surrounding landscapes. On the other hand, perhaps because they feel disconnected to natural areas, many urban area dwellers have a partial to minimum understanding of the water cycle and their place in a watershed (Geoghegan et al. 2003). It follows, then, that urban area dwellers do not see the value of green or forested riparian areas and their connection to water management, as was found in the case of urban forest in Puerto Rico (López-Marrero et al. 2011).

It is important to note that, by definition, those who live under water scarcity conditions tend to inherently practice water conservation. Corral-Verdugo, Bechtel and Fraijo-Sing (2003) found that higher income and larger residences are usually greater water consumers and facilitate further water uses (associated pools and gardens). In the insular Caribbean, the direct contrast in water consumption practices can be observed when we compare the local rural residents, who have deficient and intermittent water access, with the water-enriched environment experienced by the transient tourist in an all-inclusive facility, with full time water access. For these different groups, the connections between water management and conservation needs are perceived differently. Each Caribbean island has the obligation to provide specific, culturallysensitive knowledge and approaches that will, then, pave the way towards acceptable and integrated water conservation practices to meet societal needs (John 2006). In this way, people will be prepared to engage in greater participation and governance of their resources. 
Box 5. Freshwater Resources situation in Haïti

Adapted from Republique D’Haïti, 2001.

Major threats to management of freshwater ecosystems

- Over exploitation of the forest resources and erosion of drainage basins

Forests have been steadily exploited for basic human needs such as wood for construction, as a source of energy and as an expendable resource in the clearing of land for agriculture development.

- At present, of the thirty (30) major watersheds within the country, twenty five (25) are completely deforested. It has been estimated that less than $3 \%$ of the land surface currently remains forested.

- Due to massive deforestation and increasing erosion, the hydrological process are disrupted

Described as "Phénomène des rivières sèches" is the fact that while many wetlands and rivers are frequently subject to flooding, many river systems also do not have permanent water flow.

- Mismanagement and non-sustainable use of groundwater

Aquifers are polluted due to open latrines, quarries, sewage and uncontrolled water pumping.

\section{Urgent needs}

- Less than half of the Haitian population has access to drinking water.

- No systems of waste water treatment are in existence.

Appropriate re-use of some of these waters with basic partial treatment could easily respond to agricultural irrigation needs and help overcome part of the water crisis in the country.

- Solid waste and agricultural run-off represent major sources of land-based pollution to watersheds in Haïti. This is solid waste management for urban areas and lack of proper latrines in rural areas.

- Water-related diseases still prevail in rural areas where potable water systems are deficient or non-existent.

- Inventory of key existing information as related to resources such as groundwater, sources of drinking water, wetlands, and potential sites for restoration.

- Geographic Information Systems to describe location of water resources and critical watersheds.

- Financial resources to develop programs related to waste water \& sewage management, and safe drinking water acces.

\section{The Future of Water Management Practices in the Caribbean: A Few Recommendations}

Based on the presented information, as well as within the environmental framework perspective, the following points are recommended as actionable items and opportunities to further empower the ongoing efforts related to water resources management in the Caribbean region:

- Achieving a greater degree of community involvement is still a working goal in the insular Caribbean. Integrating users, 
communities and managers is the only way to move forward.

- More attention needs to be given to stakeholders in rural, mountainous regions; investing on education and employment alternatives will pay off with ease of management at the sources of freshwater systems.

- Local institutions must continuously train the current and future generations that will work on Integrated Water Resources Management efforts.

- Ensure continued support by facilitating, monitoring, training and educating so that the water served in community systems can be safely managed.

- The mapping of critical watersheds and recharge areas must be carried out at tandem with development of land use planning frameworks; these efforts will help to identify water resources at the local and regional scales, as well as stakeholders, and aid in management and decision-making processes (Box 5).

- Incentive-based strategies for water management must be put in place and supported by local governments.

- Awareness through education and monitoring campaigns must also take place in rapid changing urban and suburban areas, where most of the waste water management needs are concentrated.

- Governments should look to invest in repairing, improving or upgrading existing delivery systems; it is also imperative that further investments be sought for developing wastewater management systems.

- Incentivize and promote architectural and engineering efforts that improve the management of urban waters, including minimizing runoff and maximizing the recharge capacity of soils to improve urban river water quality.

- Safe rainfall harvesting, storage and delivery technologies must be supported, along with the use of alternative (solar) energies for water-processing.

- Considering that many Caribbean islands suffer from real inequities in terms of access to safe potable water, compounded by deficiencies in wastewater and sewage management, measures should be taken to improve the current situation and reach sustainable development goals.

"A lot will be gained when we change our approach to water as 
consumable good, to that of reaching the objectives of water usage. There is no reason to compromise human well-being through strict measures that enforce making less water available." Peter Gleick

"Water is the most critical resource issue of our lifetime and our children's lifetime. The health of our waters is the principal measure of how we live on the land." Luna Leopold

\section{Acknowledgements}

The staff of the USFS-International Institute of Tropical Forestry library and coworkers facilitated documents. Elizabeth Scalley Torres and Adriana Santiago commented on early stages of manuscript development. Fred N. Scatena and two anonymous reviewers provided recommendations and useful comments. Editorial assistance was provided by Gabriela González Izquierdo. Mariano Solórzano kindly translated the abstract to French. The findings, conclusions, and views expressed in this report are those of the author and do not necessarily represent the views of the U.S. Forest Service.

\section{Notes}

1. According to $\mathrm{Ng}$, Jones and Beswick (1992), groundwater freshwater lenses are a vital groundwater reservoir within Caribbean islands limestone aquifers. Also known as Ghyzen-Hertzberg lenses, these freshwater resources are recharged exclusively by infiltration of rainfall that does not runoff to the sea or is lost due to consumption (evapotranspiration) by vegetation. Because of the high infiltration and movement rates of the freshwater in these systems, there is a very limited capacity to store freshwater in these aquifers. As the less dense freshwater floats on top, the aquifers are mostly composed of the brackish and saline water layers. Because of this, both the tides from the Caribbean Sea and the intensity of rainfall events affect the location and depth of the freshwater in these deposits.

2. The ecological concept of carrying capacity is defined as the number of individuals in a population that the resources available (e.g., freshwater) in a particular site can support. Carrying capacity is represented as the plateau or maximum values to maintain stable population growth without exceeding the capacity of the environment that would lead the population to crash or oscillate precipitously. 
3. Started in 2005, the Program to Save and Use Water Rationally, or Programa de Ahorro y Uso Racionaldel Agua (PAURA), at < http:// www.hidro.cu/paura.htm >, has promoted new habits of water consumption and provided practical advice for daily life situations in order to minimize and eliminate water losses.

\section{References}

Anguilla, Government of, 2005. Anguilla National Environmental Management Strategy and Action Plan 2005-2009. Prepared by Floyd Homer.

Baisre, Julio A. and Zenaida Arboleya. 2006. "Going Against the Flow: Effects of River Damming in Cuban Fisheries." Fisheries Research 81:283-292.

Beaulac, Michael N. and Kenneth H. Reckhow. 1982. "An Examination of Land Use-Nutrient Export Relationships.” Journal of the American Water Resources Association 18:1013-1024.

Brown, Nicole, Tighe Geoghegan, and Yves Renard. 2007. A Situation Analysis for the Wider Caribbean. Gland, Switzerland: IUCN.

Caribbean Environmental Health Institute (CEHI). 2009a. "Road Map Towards Integrated Water Resources Management Planning for Barbados." Castries, St. Lucia.

- 2009b. Rainwater, Catch It While You Can: A Handbook on Rain Water Harvesting in the Caribbean.

Caribbean Natural Resource Institute (CANARI). 2005. "Governance and Civil Society Participation in Sustainable Development in the Caribbean." CANARI Policy Brief No. 7, Trinidad and Tobago.

Cashman, Adrian and Richard Ashley. 2008. "Costing the Long-Term Demand for Water Sector Infrastructure.” Foresight 10(3):9-26.

and J. Daniel. 2008. "Water Policy Development in the Caribbean: An Overview of Developments, IWRM and the Incorporation of Climate Change." Fourth Caribbean environmental forum on "Climate Change, Water and Sanitation: A Shared Responsibility" held from June 23 to 27, 2008, at Grenada Trade Centre, Grand Anse, Grenada.

_ Leonard Nurse, and Charlery John. 2010. "Climate Change in the Caribbean: The Water Management Implications.” The Journal for Environment and Development 19(1):42-67.

Cant, Richard V. and Philip S. Weech. 1986. "A Review of the Factors Affecting the Development of Ghyben-Hertzberg Lenses in the Bahamas." Journal of Hydrology 84(3):333-343.

Corral-Verdugo, Víctor, Robert B. Bechtel, and Blanca Fraijo-Sing. 2003. "Environmental Beliefs and Water Conservation: An Empirical Study". Journal of Environmental Psychology 23:247-257.

Cooper, Brian and Vincent Bowen, compilers. 2001. Integrating Management of 
Watersheds \& Coastal Areas in Small Island Developing States of the Caribbean. National Report for Antigua \& Barbuda. Environment Division, Ministry of Tourism and Environment.

Cuba, República de Cuba. 2001. Integrating Management of Watersheds and Coastal Areas in Caribbean SIDS. Reporte Nacional.

De León, Osiris. 2012. "Agua potable y saneamiento en la República Dominicana." Pp. 421-435 in Red Interamericana de Academias de Ciencias (IANAS) and Foro Consultivo Científico y Tecnológico (FCCyT). Diagnóstico del agua en las Américas.

Debrot, Adolphe O. and Rob W.M. van Soest. 2001. "First Records of the Freshwater Sponges Corvoheteromeyenia Heterosclera and Spongilla Alba (Porifera: Spongillidae) from Curacao, with Species Descriptions and Data from Transplantation Experiments." Caribbean Journal of Science 37:88-94.

— 2003. "A Review of the Freshwater Fishes of Curaçao, with Comments on those of Aruba and Bonaire." Caribbean Journal of Science 39(1):100-108.

Departamento de Recursos Naturales y Ambientales de Puerto Rico (DRNAPR). 2008. "Plan Integral de Recursos de Agua." < http://www.drna.gobierno. $\mathrm{pr} /$ oficinas/saux/secretaria-auxiliar-de-planificacion-integral/planagua/planintegral-de-recursos-de-agua-de-puerto-rico $>$. Retrieved on September 30, 2012.

Falkenmark, Malin, Jan Lundqvist, and Carl Widstrand. 1989. "Coping with Water Scarcity Requires Micro-Scale Approaches: Aspects of Vulnerability in Semi-Arid Development." Natural Resources Forum 13:258-267.

Farrell, David, Leo Moseley, and Leonard Nurse. 2007. "Managing Water Resources in the Face of Climate Change: A Caribbean Perspective." Proceedings of the 8th Annual Sir Arthur Lewis Institute of Social and Economic Studies (SALISES) Conference, UWI, St. Augustine, Trinidad, March 26-28.

Food and Agriculture Organization (FAO). 2012. "Aquastat, Irrigation. Latin America and the Caribbean.” Accessed July 30, 2012. (http://www.fao.org/ nr/water/aquastat/countries_regions/lac/index5.stm).

Gardner, Lloyd, Stevie Henry, and Toni Thomas. 2008. Watercourses as Landscapes in the U.S. Virgin Islands: State of Knowledge. U.S. Virgin Islands: Water Resources Research Institute, University of the Virgin Islands.

Geoghegan, Tighe. 2002. "Incentives for Watershed Management in St. Lucia: Results of a Brief Diagnostic.” CANARI Technical Report No. 317, Caribbean Natural Resources Institute, Laventille, Trinidad.

_- Vijay Krishnarayan, Dennis Pantin, and Steve Bass. 2003. "Incentives for Watershed Management in the Caribbean: Diagnostic Studies in Grenada, Jamaica, St. Lucia and Trinidad.” Discussion paper 60, Caribbean Natural Resources Institute, Laventille, Trinidad and International Institute for Environment and Development, London (www.iied.org).

Gleick, Peter H. 2003. "Global Freshwater Resources: Soft-Path Solutions for the 21st Century." Science 302:1524-1528. 
2006. "Desalinization, with a Grain of Salt.” Accessed July 2012. < http:// www.pacinst.org/reports/desalination/index.htm>.

Gomi, Takashi, Roy C. Sidle, and John S. Richardson. 2009." Understanding Processes and Downstream Linkages of Headwater Systems." Bioscience 52:905-916.

Greathouse, Effie A., Catherine M. Pringle, and John G. Holmquist. 2006. "Conservation Management of Migratory Fauna: Dams in Tropical Streams of Puerto Rico." Aquatic Conservation: Marine and Freshwater Ecosystems 16:695-712.

Haiti, Republique D'Haïti. 2001. Integrating the Management of Watersheds and Coastal Areas in Haiti. Haïti National Report.

Hunter, John M. and Sonia I. Arbona. 1995 "Paradise Lost: An Introduction to the Geography of Water Pollution in Puerto Rico." Social Science \& Medicine 40:1331-1355.

John, Lyndon. 2006. "From Growing Ganja to Planting Trees: Stimulating Legal Livelihoods and Watershed Management in Saint Vincent through Payments from Public Utilities." CANARI Who Pays for Water Project Document No. 2.

- and Dan Firth. 2005. "Water, Watersheds, Forests and Poverty Reduction: A Caribbean Perspective.” International Forestry Review 7:311-319.

Johnson, Jason A. and Bwalya J. Mwansa. 2007. "Development of Water Reuse Regulations and the Implementation of Water Augmentation Strategies. A Case Study of the Barbados Water Authority.” Pp. 4843-4859 in Proceedings, Water Environment Federation, WEFTEC 2007.

Lintner, Benjamin R., Michela Biasutti, Noah S. Diffenbaugh et al. 2012. "Amplification of Wet and Dry Month Occurrence over Tropical Land Regions in Response to Global Warming." Journal of Geophysical Research Atmospheres 117: D11106, doi:10.1029/2012JD017499.

López-Marrero, Tania, Marianne Meyn, Hedy I. Nieves-Crespo, Roberto Morales-López, and Nicole M. Balloffet. 2011. "Public Knowledge and Perceptions about Urban Forests in a Watershed Context. Cono Bosque Briefing." San Juan, PR: Misión Industrial de Puerto Rico.

March, James G., Jonathan P. Benstead, Catherine M. Pringle, and Frederick N. Scatena. 2003. "Damming Tropical Islands Streams: Problems, Solutions, and Alternatives." Bioscience 53(11):1069-1071.

Minnigh, Harvey A. and Graciela I. Ramírez Toro. 2001. "Valuing Water in Rural Puerto Rico. Globalization and Water Resources Management: The Changing Value of Water”. Proceedings, American Water Resources Association.

Ng, Kwok-Choi, Brian Jones, and Richard Beswick. 1992.” Hydrogeology of Grand Cayman, British West Indies: A Karsticdolostone Aquifer.” Journal of Hydrology 134(1):273-295.

Ortiz-Zayas, Jorge R. and Frederick N. Scatena. 2004. "Integrated Water Resources Management in the Luquillo Mountains, Puerto Rico: An Evolv- 
ing Process." International Journal of Water Resources and Development 20(3):387-398.

Ramos-Scharrón, Carlos E. and Lee H. MacDonald. 2007. "Measurement and Prediction of Natural and Anthropogenic Sediment Sources, St. John, U.S. Virgin Islands.” Catena 71:250-266.

Rogers, Peter. 2002. "Water Governance in Latin America and the Caribbean." Draft for presentation at the Inter-American Development Bank's Annual Meeting in Fortaleza, Brazil, March 7, 2002. Inter-American Development Bank, Sustainable Development Department, Environment Division.

Scatena, Frederick N. 2004. "A Survey of Methods for Setting Minimum Instream Flow Standards in the Caribbean Basin." River Research and Applications 20:127-135.

__ Jorge R. Ortiz-Zayas, and Juan F. Blanco-Libreros. 2008. "Helping HELP with Limited Resources: The Luquillo Experience.” Water SA (34):4. <URL: http://www.wrc.org.za/publications_watersa_sa_help_sp_edition. htm, and http://repository.upenn.edu/ees_papers/55>.

Schneiderman, Jill S. and Rhoda Reddock. 2004. "Water, Women and Community in Trinidad, West Indies." Natural Resources Forum 28:179-188.

Steward, Alisha L., Daniel von Schiller, Klement Tockner et al. 2012. "When the River Runs Dry: Human and Ecological Values of Dry Riverbeds." Frontiers in Ecology and the Environment 10:202-209.

Taylor, Michael A., Tannecia S. Stephenson, A. Anthony Chen, and Kimberly A. Stephenson. 2012. "Climate Change and the Caribbean: Review and Response". Caribbean Studies (this issue).

Thorn, Ronald M., Amy B. Borde, Klaus O. Richter, and Lyle F. Hibler. 2001. "Influence of Urbanization on Ecological Processes in Wetlands." Pp. 5-16 in Land Use and Watersheds: Human Influence on Hydrology and Geomorphology in Urban and Forest Areas. (Water Science and Application 2), edited by M.S. Wigmosta and S.J. Burges. Washington, DC: American Geophysical Union.

van Sambeek, Michael H.G., Hermanus Gerardus Maria Eggenkamp, and M.J.M Vissers. 2000. "The Ground Water Quality of Aruba, Bonaire and Curaçao: A Hydrogeochemical Study." Netherlands Journal of Geosciences 79(4):459-466.

Voutchkov, Nikolay. 2011. "Overview of Seawater Concentrate Disposal Alternatives." Desalinization 273:205-219.

Young-George, Christine, Robin Mahon, and Janice Cumberbatch. 2007. "An Environmental Assessment of the Accommodation Sector in the Grenadine Islands.” CERMES Technical Report No. 13, Centre for Resource Management and Environmental Studies, University of the West Indies, Faculty of Pure and Applied Sciences, Cave Hill Campus, Barbados.

Zack, Allen and Matt C. Larsen. 1994. "Island Hydrology: Puerto Rico and the U.S. Virgin Islands." National Geographic Research \& Exploration, Water Issue. 